\title{
Reflections of Mathematical and Mathematics Educational Values on Pedagogical Formation Students' Teaching Preferences
}

\author{
Seher Mandaci Şahin ${ }^{\circledR}$ \\ Ilknur Özpinar' ${ }^{\mathbb{D}}$
}

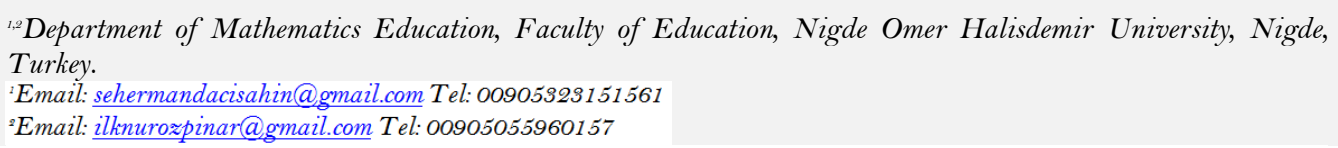

\section{Abstract}

As in all fields, values are an important component of classroom's affective environment in mathematics course, too, and have a significant impact on students' mathematical efforts. As it would directly affect classroom practices and learning, it is deemed important to determine preservice teachers' value profiles. This research aimed to address mathematical and mathematics educational values of mathematics students receiving pedagogical formation in terms of constructivist and positivist approaches and examine these values along with their opinions on the use of different teaching strategies, methods and techniques (SMTs) in courses. The participants were 288 mathematics students receiving pedagogical formation at two public universities. As data collection instruments, Mathematical and Mathematics Educational Values Scale and a written interview form were used to associate their values with their teaching preferences. The study concluded a significant difference in favor of constructivist values when comparing participants' levels of having positivist values with their levels of constructivist values. The findings achieved from the interview forms indicated that majority of participants preferred student-centered teaching strategies, methods and techniques; in other words, they regarded themselves rather as constructivists.

Keywords: Mathematical values, Mathematics educational values, Constructivist and positivist approaches, Teaching preferences, Pedagogical formation certificate program, Teacher candidates.

Citation | Seher Mandaci Şahin; Ilknur Özpinar (2020). Reflections of Mathematical and Mathematics Educational Values on Pedagogical Formation Students' Teaching Preferences. Asian Journal of Education and Training, 6(1): 80-92

\section{History:}

Received: 15 November 2019

Revised: 23 December 2019

Accepted: 29 January 2020

Published: 24 February 2020

Licensed: This work is licensed under a Creative Commons

Attribution 3.0 License (co)

Publisher: Asian Online Journal Publishing Group
Acknowledgement: Both authors contributed to the conception and design of the study.

Funding: This study received no specific financial support.

Competing Interests: The authors declare that they have no conflict of interests.

Transparency: The authors confirm that the manuscript is an honest, accurate, and transparent account of the study was reported; that no vital features of the study have been omitted; and that any discrepancies from the study as planned have been explained.

Ethical: This study follows all ethical practices during writing.

\section{Contents}

1. Introduction 81

2. Method 82

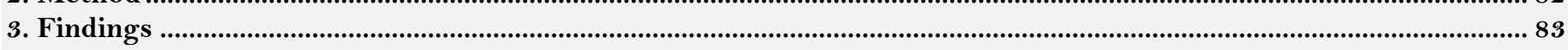

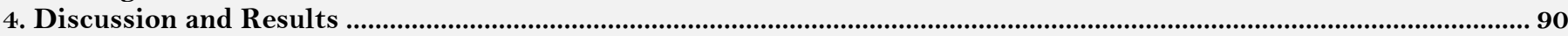

References. 


\section{Contribution of this paper to the literature}

The 'mathematical and mathematics educational values' is a topic need to be stressed out in mathematics education as they would directly affect classroom practices and learning. In this research, mathematical and mathematics educational values of mathematics students addressed in terms of constructivist and positivist approaches and examined these values along with their opinions on the use of different teaching strategies, methods and techniques (SMTs) in courses. Hereby, it is believed that educators will reach important clues to make self-check on this subject.

\section{Introduction}

One of the most important elements in the educational system is teachers beyond any doubt. Teacher training has been conducted within the responsibility of Faculties of Education for long years but different practices have been resorted to for satisfying the increasing need for qualified personnel in certain periods and alternative programs have been applied in teacher training. One of these practices is pedagogical formation training which allows individuals who graduated from different faculties to receive a certificate if the required conditions are met and to teach as a profession (Kartal and Afacan, 2012; Tepeli and Caner, 2014). Introduced as a result of the thought that teachers trained in faculties of education especially in the US had insufficient content knowledge by 1950s, Pedagogical Formation Training is a certificate program that gives individuals who graduated from different faculties the chance to become teachers (Yenice and Ozden, 2017). However, this practice brought about the problem of training qualified teachers. Content knowledge is an important attribute that preservice teachers should possess; however, there are other competencies that teachers need to have. If teachers trained do not have the required competencies, the desired outcome in education-instruction will cannot be achieved (Arslan and Ozpinar, 2008). Hence, success of educational system depends on qualified teachers who have content knowledge and pedagogical content knowledge. Yet, teaching is a profession that requires affective content competencies as well as cognitive content competencies (Kartal et al., 2012).

Teachers of future need to have sufficient knowledge in topics such as content knowledge, methodological knowledge and instructional techniques and to get an idea of when and how to apply what they know in teachinglearning environments. In this century, teachers are expected to be equipped with knowledge on instructional technologies, computer-aided teaching and pedagogical content knowledge as well as content knowledge. It is aimed with the knowledge acquired in teaching formation that preservice teachers learn how to use this knowledge in case of issues encountered in the practice and in problem solving and that special teaching methods used in the domain in regard to this training are learned (Mustang, 2002).

Today, it is stated that curricula should be prepared in a conceptual approach (MEB, 2013). This brings along the adoption of contemporary learning approaches such as multiple intelligence theory and instruction sensitive to individual differences as well as activity, student-centricity and thematic approach (Gömleksiz and Kan, 2007). Thus, curricula aim the transformation of mathematics classrooms into active learning environments where mathematics is not presented but performed, and accordingly, they assign the role of a guide beyond being an explainer to teachers and the role of an inquirer beyond being a listener to students (MEB, 2013). Some of the important factors by which teachers are influenced when playing this role are their philosophies and ideals (Mustang, 2002). Reflections of these philosophies and ideals in learning environment appear to be the values possessed by teachers.

Values have a key role within factors affecting the teaching-learning process. Indeed, mathematical values are available in the vision and general objectives of the mathematics curriculum although they are not directly mentioned in it Dede (2006a); Kus (2009). Opinions on values in education differ by their philosophical and moral sources and the nature of the related domain. No agreement on the term "value" is observed in the literature (Lim and Ernest, 1997). It is therefore quite difficult to define value (Swanader and Soedjadi, 1988). Given the definitions made in the literature, it is possible to say that values, as one of the cognitive domain factors, refer to concepts or ideas that an individual create about the importance of something or that they are abstractions which will help explore the importance of something (Swanader and Soedjadi, 1988; Dede, 2006a). Based on this definition, values can be considered as our judgements about what is good and bad (Swanader and Soedjadi, 1988). Values play an important role in defining personal and social identities and are about the idea that a phenomenon is important or not (Dede, 2006a; Pathania, 2011). As in all domains, values are an important component of classroom's affective environment in mathematics course, too, and therefore, have a significant impact on students' mathematical efforts (FitzSimons et al., 2001). Bishop et al. (1999) addressed values about mathematics teaching in three main headings: general educational values, mathematical values and mathematics educational values. General educational values include moral values such as integrity, helpfulness, courtesy, responsibility, and humility. Mathematical values refer to values that reflect the nature of mathematical knowledge such as rationality-objectivism, control-progress, and openness-mystery. Some of the mathematics educational values corresponding to these values include accuracy, openness, estimation, consistency, creativity, effective organization, liking, flexibility, open-mindedness, continuity, and systematical study (Bishop et al., 1999; Seah et al., 2001). Durmus et al. (2008) mentioned that these said values represent the values based on objectivist (positivist-behavioral and cognitive approaches) and subjective (constructivist approach) foundations and classified values of control, privacy, accuracy as objective values and values of rationality, progress, creativity, entertainment, flexibility and open-mindedness values as subjective values, and they included the openness value in both groups.

Since values are about the perception of world, there are differences in line with the philosophical perspective. Hence, approaches in education include their own values. Behavioral and cognitive approaches assume that knowledge is independent of individual, which results in the transfer of information to learner. Learners happen to acquire the information which exists regardless of them in the way that their teachers present it using certain methods, and behaviors desired in learners should be particularly highlighted by teachers (Baki, 2008; Temizöz and Ozgün-Koca, 2008). Such practices are called traditional approaches in the literature (Castronova, 2002). On the other hand, according to the constructivist approach, information is not independent of individual and cannot be 
directly transferred from one to another. When such perspective is taken for the nature of knowledge, the authority in the construction or acquisition of information is learner themselves (Baki, 2008; Temizöz and Ozgün-Koca, 2008).

Although it is about values in education, its investigation in mathematics education is somewhat a new domain, and the pioneering studies started by Bishop, Clarkson and their colleagues with Values in Mathematics Project (VAMP) in Australia (Bishop et al., 1999). In the literature, there are several studies on values in mathematics education. Some of these studies address the measurement of mathematics educational values (Durmus and Biçak, 2006; Dede, 2009; Luttrell et al., 2010; Liman et al., 2013; Pa and Tapsir, 2013) the examination of mathematical values in mathematics course books (Cao et al., 2006; Dede, 2006a;2006b) and similarities and differences between the values of mathematics and science teachers (Bishop et al., 2006; Bishop, 2008). Studies on mathematical and mathematics educational values in Turkey are in limited number and their samples consist of preservice teachers attending the faculties of education or in-service teachers (Durmus and Bıçak, 2006; Durmus et al., 2008; Dede, 2009; Durmus, 2011). Durmus et al. (2008) classified values in two main categories (positivist-objective, constructivist-subjective) and aimed to explore the values of primary education teachers. They concluded that the participants regarded themselves rather as objectivists (constructivists) in regard to mathematical and mathematics educational values. In the study examining the mathematics teaching values of preservice primary and secondary education teachers, Dede (2009) found that the participants had higher levels of accepting the constructivist values than the levels of accepting positivist levels. Durmus (2011) examined the value profiles of preservice teachers studying in the final year of the department of mathematics teaching and concluded a significant difference in favor of constructivist values in the comparison between levels of having positivist values and constructivist values. Given the studies performed with preservice teachers receiving pedagogical formation training, it is observed that their opinions on teaching practice have been received (Tepeli and Caner, 2014; Biber and Tuna, 2015) their attitudes toward teaching profession have been examined (Eraslan and Cakıci, 2011; Kartal and Afacan, 2012; Ozkan, 2012; Polat, 2013) it has been aimed to identify their metaphors (Dündar and Karaca, 2013; Nartgün and Gökçer, 2014) and their professional competencies have been investigated (Adıgüzel, 2013; Süral and Sarıtas, 2015).

Most of the studies conducted to date on teachers' thoughts on mathematics teaching and their classroom behaviors in the literature showed that there was a similarity between the thoughts and classroom practices of teachers (Temizöz and Ozgün-Koca, 2008). However, many mathematics teachers do not consider that they reflect some of their values during their instruction. Changing this perception comes across as one of the greatest obstacles to be overcome (Bishop, 2001). Values reflected by teachers in mathematics classrooms are also associated with their pedagogical identities (Chin et al., 2001) and directly affect the practices in the classroom setting. For instance, teachers who regard mathematics as being open to everyone, esthetical and logical would expect their students to structure mathematical knowledge in their own ways (Durmus et al., 2008). Values are a topic to be stressed out in mathematics education as they would directly affect classroom practices and learning (Bishop, 2001; Durmus et al., 2008). Furthermore, importance of approaches utilized by teachers in their instructions and the effect of their opinions on the use of different teaching approaches on teaching practices cannot be ignored (Temizöz and Ozgün-Koca, 2008). Since teachers relay values to their students either implicitly or explicitly during the teachinglearning process with such importance of values having come into the open (Bishop et al., 1999; Bishop, 2001) it is deemed important to determine value profiles of pedagogical formation students as well as preservice teachers who will graduate from faculties of education and to examine these values along with their opinions on practices of the teaching-learning process. To this end, this research addressed mathematical and mathematics educational values of mathematics students receiving pedagogical formation in terms of constructivist and positivist approaches and examined these values along with their opinions on the use of different teaching strategies, methods and techniques (SMTs) in courses. In line with this aim, the main research problem is "Are mathematical and mathematics educational values of mathematics students who receive pedagogical formation training effective on teaching SMTs they prefer to use?" The sub problems to be investigated in the context of this main problem include:

i) What approaches do mathematics students receiving pedagogical formation training have in regard to mathematical and mathematics educational values?

ii) Are genders of mathematics students receiving pedagogical formation training effective on their mathematical and mathematics educational values?

iii) Are mathematical and mathematics educational values of mathematics students receiving pedagogical formation training associated with their previous learning experiences?

iv) Do mathematical and mathematics educational values of mathematics students receiving pedagogical formation training affect their preferences of teaching SMTs and their designs of learning environment?

\section{Method}

2.1. Study Group

In this study aiming to address mathematical and mathematics educational values of mathematics students receiving pedagogical formation training in regard to constructivist and positivist approaches and to examine them along with their opinions on the use of different teaching SMTs in courses, the participants were 288 students attending the Department of Mathematics in Faculty of Arts and Sciences at two public universities in Central Anatolian Region (126) and Black Sea Region (162). The study was performed during the Special Teaching Methods course in the Pedagogical Formation Training Program.

Special Teaching Methods Course cover general objectives of pedagogical content knowledge; methods, strategies, instruments and materials; detailed examination of curriculum of the related field; main field-specific concepts, relationship between these concepts and pedagogical content knowledge, and classroom practices. During the classroom practices, the students were informed of teaching and learning SMTs based on group work, problem solving, learning by exploring, expository teaching, demonstration, trip-observation, roleplaying (drama), case study, definitions, experimental activities, games and computer-aided teaching (Alkan and Altun, 1998; Altun, 
2004; Baki, 2008; Altun, 2014). Next, it was ensured that the students designed learning-teaching processes and conducted micro applications in the mathematics classrooms.

\subsection{Data Collection Instruments}

In this study, the "Mathematical and Mathematics Educational Values Scale" developed by Durmus and Bıçak (2006) was applied to the participants in the first place. The 5-point Likert scale consisting of 2 factors and 34 items (14 items for positivist values, 20 items for constructivist values) have a Cronbach's Alpha internal consistency coefficient of 0.73 while other internal consistency coefficients are 0.64 for positivist items and 0.74 for constructivist items. The scale items were evaluated in accordance with the criteria in Table 1. Cronbach's Alpha internal consistency coefficient calculated for the data that were collected in this study was found to be 0.86 . The ranges accepted for the scale items are given in Table 1.

\begin{tabular}{l|c|c|c|c|c}
\multicolumn{7}{c}{ Table-1. Item Ranges for mathematical and mathematics educational values. } \\
\hline Option & Strongly disagree & Disagree & Neutral & Agree & Strongly agree \\
\hline Weight & 1 & 2 & 3 & 4 & 5 \\
\hline Limits & $1.00-1.79$ & $1.80-2.59$ & $2.60-3.39$ & $3.40-4.19$ & $4.20-5.00$ \\
\hline Source: Durmus and Biçak (2006).
\end{tabular}

Other than this scale, the participants were asked to answer the four-question interview form prepared to associate their values and teaching methods. The questions asked to the participants are as follows: 1) Considering the teaching methods presented to you in your educational life and the special teaching methods you have learned in this course, which methods do you think are more effective and efficient? Explain with your reasons. 2) Discuss the efficacy of special teaching methods. 3) Which methods do you think are difficult to apply in mathematics education and why? 4) Which teaching SMTs would you prefer mainly in the teaching process? Explain with reasons. Draw an image of the classroom environment in which you plan to use the said teaching strategy, method and technique.

\subsection{Data Analysis}

In accordance with the aim of study, two data collection instruments were utilized: Mathematical and Mathematics Educational Values Scale and written interview form for exploring the effect of participants' values on their preferred teaching SMTs. The quantitative data achieved were analyzed on SPSS software package.

The qualitative data were subjected to a content analysis. First, SMTs experienced by the participants in their previous educational lives were grouped to create percentage-frequency tables. Next, the answers about teaching SMTs which they thought were effective and efficient, were difficult to use and they would prefer to use in the future, and their percentages and frequencies were calculated. Lastly, the quantitative data were interpreted with the qualitative data achieved from drawings and explanations and presented in findings. This allowed for the explanation of the justifications for the quantitative data. The participants were coded as $\mathrm{S} 1, \mathrm{~S} 2, \mathrm{~S} 3 \ldots$ in the data analysis.

\section{Findings}

This section addresses the values of the participants and presents the findings achieved from participant opinions.

\subsection{Analysis of Data Achieved in Mathematical and Mathematics Educational Values Scale}

Mathematical and mathematics educational values of the participants receiving pedagogical formation training were examined by whether being constructivist or positivist and are given in Table 2. Despite being from different universities, all participants were gathered in a single group, and a dependent $t$ test was performed as it was aimed to examine two different values with a single scale which was applied to all of them.

\begin{tabular}{c|c|c|c|c|c|c}
\multicolumn{8}{c}{ Table-2. Dependent test results concerning the participants' values. } & $\mathbf{t}$ & $\mathbf{p}$ \\
\hline Values & $\mathbf{N}$ & $\bar{X}$ & $\mathbf{S}$ & SD & & \\
\hline Constructivist & 288 & 3.65 & 0.38 & & & \\
\hline Positivist & 288 & 3.06 & 0.47 & 287 & 20.59 & $.000^{*}$ \\
\hline Note: ${ }^{*}$ p $<.05$ significance level.
\end{tabular}

Table 2 shows that mean values of participants' constructivist values were on the level of "I agree" $(\bar{X}=3.65)$ while mean values of participants' positivist values were on the level of "neutral" ( $\bar{X}=3.06)$. According to the table, there was a significant difference in favor of constructivist values when comparing participants' levels of having positivist values with their levels of constructivist values $(\mathrm{p}<.05)$.

The analysis results concerning whether gender that was mentioned among the sub problems of the research had any effect on their values are given in Table 3. Since 3 of the participants left the gender area blank in the scale form, analyses were conducted with the remaining 285 participants.

Table-3. Independent t Test Results Concerning the Participants' Values by Gender.

\begin{tabular}{c|c|c|c|c|c|c|c}
\hline Values & Gender & $\mathbf{N}$ & $\bar{X}$ & $\mathbf{S}$ & $\mathbf{S D}$ & $\mathbf{t}$ & $\mathbf{p}$ \\
\hline \multirow{2}{*}{ Constructivist } & Male & 105 & 3.56 & 0.39 & 283 & 3,142 & \multirow{2}{*}{0.002} \\
\cline { 2 - 6 } & Female & 180 & 3.7 & 0.36 & & & \\
\hline \multirow{2}{*}{ Positivist } & Male & 105 & 3.16 & 0.45 & 283 & 0,789 & 0.431 \\
\cline { 2 - 6 } & Female & 180 & 3.11 & 0.45 & & & \\
\hline
\end{tabular}

Note: $* \mathrm{p}<.05$ significance level. 
According to Table 3, female $(\bar{X}=3.56)$ and male $(\bar{X}=3.70)$ participants had constructivist values on the level of "I agree". By gender, a significant difference was found in favor of female participants between male and female participants with constructivist values. It is also seen in Table 3 that both male $(\bar{X}=3.16)$ and female $(\bar{X}=3.11)$ participants had positivist values on the level of "neutral" and there was no significant difference between the participants with positivist values by gender.

\subsection{Opinions of the Mathematics Students Receiving Pedagogical Formation Training on Teaching SMTs Used} in Mathematics Course

To explore the effect of participants' values on their preferred teaching SMTs, a written interview form composed of four open-ended questions were applied to them. Firstly, the participants were asked to explain which teaching SMTs are more efficient in teaching with its reasons in consideration of the teaching SMTs presented to them in their previous educational lives and the special teaching methods they had learned in the pedagogical formation training. SMTs experienced by the participants in their previous educational lives are presented in frequency (f) and percentage (\%) in Table 4.

Table-4. Frequencies and percentages of SMTs experienced by the participants in their previous educational lives.

\begin{tabular}{|c|c|c|}
\hline Method & f & $\%$ \\
\hline Expository teaching & 269 & 93.40 \\
\hline Learning by exploring & 16 & 5.55 \\
\hline Group work & 3 & 1.04 \\
\hline Computer-aided teaching (CAT) & 2 & 0.69 \\
\hline Teaching by scenario & 1 & 0.35 \\
\hline
\end{tabular}

It is seen in Table 4 that majority of the participants had been mostly taught with expository teaching in their educational lives. The following are brief citations from the participant opinions on this matter:

"We've been taught with expository teaching all the time. We've done no experiments in science course or no games, explorations and practices in mathematics course." (S47)

"I've always been taught with expository teaching in my educational life. Let alone mathematics, they used to teach biology without making experiments in laboratories. It was the same with other courses; I've been taught with a teacher-centered instructional approach". (S109)

"Only the expository teaching would be used back in my time. We used to go to the laboratory in physics or chemistry courses and would not use the materials in case they would be broken. No other method than expository teaching has been used in mathematics course. None of my teachers have used it properly anyway". (S112)

"In my educational life, mathematics used to be thought with direct instruction all the time. That's why mathematics has never been beyond a difficult course for me". (S127)

"Including university, they haven't applied special teaching to us not only in mathematics but also in other courses. We've received a teacher-oriented education... by memorizing everything without even understanding it." (S141)

"Expository teaching has been used in general. I don't think it is useful. It doesn't have a long-lasting impact." (S146)

S37 and S215 stated that they had teachers who used other methods along with expository teaching, and S37 provided the following statements:

"In our biology course, computer-aided teaching, and expository teaching and exploration methods were used. These would also be supported with materials. Our teacher used to include us in the course actively all the time. These were the most productive course and teaching methods that I couldn't forget all my life."

S2 15 summarized their educational life as follows: "...It was expository instruction method in general. There would be learning by exploring in some courses. Question and answer and discussion methods would be used in the courses."

Frequency and percentage values of the participant opinions on which SMTs would be more effective and efficient to use in mathematics teaching are presented in Table 5.

Table-5. Frequency and percentage values of SMTs found more effective and efficient in mathematics teaching by the participants.

\begin{tabular}{l|c|c}
\hline Method & f & \% \\
\hline Learning by exploring & 122 & 42.36 \\
\hline Expository teaching & 57 & 19.80 \\
\hline Demonstration & 15 & 5.21 \\
\hline Group work & 11 & 3.82 \\
\hline Problem solving & 11 & 3.82 \\
\hline Teaching by scenario & 9 & 3.12 \\
\hline Teaching by games & 7 & 2.43 \\
\hline Computer-aided teaching (CAT) & 6 & 2.08 \\
\hline Case & 1 & 0.35 \\
\hline Teaching by analysis & 1 & 0.35 \\
\hline
\end{tabular}

Note: Percentages may exceed $100 \%$ because the answers of some of the participants were placed under multiple codes.

Table 5 indicates that majority of the participants found learning by exploring more effective and efficient in mathematics teaching. This method was followed by expository teaching (19.80\%, 57 students), demonstration method (5.21\%, 15 students), teaching by group work (3.82\%, 11 students), teaching by problem solving (3.82\%, 11 students), teaching by scenario (3.12\%, 9 students), teaching by games (2.43\%i 7 students), computer-aided teaching (2.08\%, 6 students), case study method (0.35\%, 1 student), and teaching by analysis (0.35\%, 1 students). Moreover, 19.80\% (57) of the participants highlighted the use of student-centered teaching methods. It is remarkable that $11.11 \%(32)$ of the participants stated that additional use of materials supports comprehension and can be used with appropriate methods. 
Among the reasons why learning by exploring is effective and efficient, the participants mentioned that students make their own research and make logical deductions, applied courses are more retentive and effective, and learning by doing-living is important. Differently from others, four participants mentioned group work and stated that student should actively participate in the course while two participants would prefer discussion and brainstorming methods along with this method.

About CAT, two of the participants provided the following statements: "I think it is helpful to use technology efficiently in concretization of mathematics as it is composed of abstract concepts." (S165) and "I think smartboards play a key role in visualization on the condition of proper use." (S140). Furthermore, some of the participants did not adopt the use of a single method and suggested that methods should be chosen by topic. Two of these students explained their opinions as follows:

"I'm not a fan of using a single method in learning. Teaching method should be used according to what is required by the course. For instance, a zoo visit should be performed in biology." (S146)

"The most effective method should be chosen according to topic; not every topic can be taught with one method." (S153)

Regarding participants' experiences before the formation training and their later thoughts about methods to be used in mathematics teaching, a small part of them stated that different methods can be used along with expository teaching as they saw it from their branch teachers in their previous educational lives but they did not have any idea about their application in mathematics course because they had never seen them used in mathematics courses. It was found that majority did not think other methods than expository teaching can be used in mathematics teaching. However, $73.96 \%$ (213) of the participants agreed that special teaching methods can be effective in mathematics teaching alongside expository teaching after they had learned these methods. Participants expressed their relevant thoughts as follows:

'I used to think that mathematics can be completely taught by expository teaching. We've always been told so; we've learned mathematics by expository teaching, even at the university. Now we've seen here in the formation training that special teaching methods are more retentive and effective. When different teaching methods appropriate for the topics are chosen, retention is achieved in teaching." (S14)

"The Special Teaching Methods course showed me how to teach more entertainingly and retentively. Honestly, I saw the steep difference with the teaching I've been performing before receiving formation..." (S16)

"You said at the beginning that how a person is educated determines how they teach. It is true, our knowledge didn't use to be very retentive. I've never thought how to teach in other ways than expository teaching that we've seen all the time... As special teaching methods are based on problem solving, thought-provoking and provide active participation for student, they are more long-lasting in their memories. (S89)

"There has been expository teaching to date. But in this formation training, I think it contributed to my 8-year experience a lot. I think I will teach in communication with my students and by making them active..." (S97)

"Among special teaching methods, expository teaching will not be effective if used alone. But course will become more effective and retentive if it is used with learning by exploring." ( $\mathrm{S} 115)$

"These methods were effective enough to make me notice that I was a rote learning-oriented teacher." (S270)

"I think learning by exploring is retentive and helpful, and expository teaching is ineffective alone." (S286)

A remarkable finding of the study is that $13.88 \%(40)$ of the participants did not find the use of special teaching methods appropriate for several reasons (educational system, class size, etc.). Relevant participant opinions are given below:

"Student-centered teaching is very difficult in the current system. Class size should be 25 on average. It is 60 here. It's very difficult to apply methods under these circumstances..." (S12)

"We've seen with formation training that not only expository teaching but also other methods are more effective and can achieve retentive learning. But activities take time. It's not possible in private sector. It takes much time to prepare materials." $(\mathrm{S} 15)$

"I think the method we've been accustomed to for years is more effective." (S52)

"Expository teaching is more effective. Information should be given directly for students to be able to learn." (S80)

"We completed our educational life with expository teaching methods. Although we've tried to be more efficient, we've been taught without asking questions due to the fear of teachers, even at university... Under these circumstances, expository teaching is more effective as it's not possible to change it although there is criticism." (S107)

"Special teaching methods have a great place in mathematics education. Expository teaching alone will cause indifference to the course among students. But I think other teachers and I don't prefer it due to lack of time, place and instrument to apply special teaching methods and as it's not fully compatible with the current exam system". (S113)

"The course is effective, but I don't think every method can be used in classroom." (S141)

"Learning by exploring is effective, but expository teaching not only saves time but also prevents confusion in some topics." (S159)

"The methods we've seen are nice but it's difficult to apply them at school." (S191)

"They are ways to make students active, but their application isn't possible due to limited class hours and the effort to teach topics on time today." (S201)

"As classrooms are crowded, these cannot be used effectively. Limited time has a negative impact, too." (S2 19).

"I've begun to think how efficient the course has been for us after seeing that the methods we've learned aren't applied at schools." (S248)

"The methods we've learned aren't suitable for our educational system. Information given at university and practices to be performed when teaching don't coincide." (S276)

"We mostly present information with expository teaching. Because time is limited, and in this way, we can reach many students at the same time." (S285)

Findings concerning the SMTs found by the participants difficult to use in mathematics teaching are presented in Table 6. 
Table-6. Frequency and percentage values of SMTs found by the participants difficult to use in mathematics teaching.

\begin{tabular}{l|c|c}
\hline Method & F & \% \\
\hline Learning by exploring & 82 & 28.47 \\
\hline Group work & 58 & 20.14 \\
\hline Teaching by scenario & 37 & 12.85 \\
\hline Expository teaching & 31 & 8.76 \\
\hline Drama & 24 & 7.29 \\
\hline Computer-aided teaching (CAT) & 21 & 5.90 \\
\hline Project-based teaching & 17 & 5.90 \\
\hline Problem solving & 17 & 0.69 \\
\hline Teaching by analysis & 2 & 0.69 \\
\hline Case study & 2 & 0.69 \\
\hline Teaching by games & 2 & 0.35 \\
\hline Demonstration & 1 & 0.35 \\
\hline Trip-observation & 1 & 0.35 \\
\hline Teaching by experimental experiences & 1 & \\
\hline Note: Percentages may exceed $100 \%$ because the answers of some of the participants were placed under multiple codes.
\end{tabular}

Note: Percentages may exceed $100 \%$ because the answers of some of the participants were placed under multiple codes.

Table 6 shows that the participants found learning by exploring and group work to be the most difficult SMTs to apply in mathematics teaching. According to the participants, the reason why these methods are difficult to use is that classrooms are mostly crowded, which would make classroom management difficult, and preparation and implementation should be well-planned and would take much time. The participants provided relevant statements as follows:

"Group work, considering the public schools, is a teaching method hard to apply because classrooms are crowded." (S37)

"Group work. Because you need to prepare individual activities, materials, etc. for each topic. That will take so much time. It's also difficult to control the class in group works." (S61)

"I find learning by exploring difficult to apply in mathematics teaching as it takes time and one can have challenges when making preparations. And I think when it's used in a crowded classroom, not all of the students can be reached as desired." $(\mathrm{S} 111)$

"Learning by exploring cannot be used all the time. It would difficult to activate student and keep the classroom under control." (S132)

"One may have difficulty with learning by exploring. Because we can lose control of the classroom while making the student active." (S275)

It's difficult with learning by exploring because time is limited, classrooms are crowded and there isn't enough time." (S170 and S288)

The participants who found learning by exploring difficult argued that providing information theoretically and direct instruction of topics would make mathematics teaching inefficient. The following are participants' relevant opinions:

"Direct instruction of topics without associating them with daily life and how students don't use the power of thinking make mathematics teaching difficult." (S127)

"I think direct instruction is difficult. Because mathematics is a course about visuals." (S187)

"Expository teaching alone is boring and means direct instruction." (S211)

Other methods that participants found difficult to use were drama and CAT. As the reasons, participants stated that it is difficult to organize the classroom and achieve activity of each student and that drama would be more effective in verbal-content courses and with smaller groups.

Three of the participants (S68, S77 and S124) mentioned about the difficulty with the combination of group work and learning by exploring in mathematics teaching. S68 provided the following statements on the matter:

“...For example, in learning by exploring and group work methods, teacher is expected to prepare appropriate activities beforehand and apply them with students. Most of the time, it's expected to use both together. This not only causes waste of time but also makes classroom management difficult..."

Differently from other participants, S40 and S98 stated that the difficulty with these methods is because teachers prefer teacher-centered teaching as it is easier and do not want to quit the expository teaching method. S105 stated that these methods are not suitable for the structure of exams in our educational system and it is necessary but difficult to use learning by exploring.

It is seen in Table 6 that part of the participants receiving pedagogical formation addressed teaching by scenario and expository teaching other than learning by exploring and group work. Participants stated that teaching by scenario is difficult to use because mathematics is an abstract course and it is very hard to prepare a scenario for it. Participants who found expository teaching difficult thought that they would have difficulty keeping students' attention alive as they are passive in this method and have trouble with enabling them to comprehend the topic.

13 participants stated that every method is applicable as long as there is enough time. One of the remarkable findings in regard to the topic is that 35 participants thought of material usage as a method. Participants who wrote down concrete material usage as a teaching method stated that material usage is a waste of time in the current exam-oriented system, concretization cannot be suitable for every subject except for geometry as mathematical concepts are abstract, and concretization is not possible at schools other than the use of smartboards.

Frequencies and percentages of the findings in regard to SMTs that would be mainly preferred by the participants in their teaching are given in Table 7. 
Table-7. Frequencies and percentages of SMTs that would be preferred by the participants in mathematics teaching.

\begin{tabular}{l|c|c}
\hline Method & $\mathbf{F}$ & $\mathbf{\%}$ \\
\hline Learning by exploring & 141 & 48.96 \\
\hline Expository teaching & 118 & 40.97 \\
\hline Group work & 49 & 3.01 \\
\hline Problem solving & 9 & 2.43 \\
\hline Computer-aided teaching & 7 & 1.77 \\
\hline Teaching by scenario & 5 & 1.04 \\
\hline Demonstration & 3 & 0.69 \\
\hline Teaching by games & 2 & 0.35 \\
\hline Teaching by analysis & 1 & 0.35 \\
\hline Case study & 1 & \\
\hline
\end{tabular}

Note: Percentages may exceed $100 \%$ because the answers of some of the participants were placed under multiple codes.

According to Table 7, learning by exploring, expository teaching, and group work are primary SMTs that would be preferred by the participants in mathematics teaching. Opinions on this topic are given below:

"I'm planning to use exploring method mainly in my teaching. Because it will help me teach more entertainingly and enjoyably and the student will find it themselves, an efficient learning will occur." (S4 and S286)

"I think learning by exploration is more effective. Because then students will remember concepts they explored more easily and will become more active." (S160 and S161)

"I think group work method is effective. It's a method in which communication among students is dominant; it can be preferred to allow them to share their ideas." (S44)

"Learning with group can be effective. It can be a good method as students will be communication when studying in a group." (S232)

"I prefer group work. Because sharing their ideas about the topic will make a social contribution and create a good environment." (S2 13) $(\mathrm{S} 126)$

"Schedule is busy and I'm teaching at a high school. I prefer expository teaching to teach more subjects in a shorter time."

"As I'm working at a private teaching institution, I have to do it in a teacher-centered way. As it is based on exam, I do and will teach by expository teaching all the time." (S147) $(\mathrm{S} 177)$

"Expository teaching in general. Although it doesn't coincide with today's teaching, I use it due to physical conditions."

21 of the participants stated that they would use expository and learning by exploring together as follows: (S59)

"I'll use expository teaching in general. But I'm thinking to utilize learning by exploring in geometry and analytics."

"I would prefer learning by exploring. Maybe partially expository teaching, too. Learning by exploring enables student to be effective. Expository teaching can be preferred by grade level and subject." (S185)

"I would prefer expository and learning by exploring. It'll be easy because there will be real learning in learning by exploring. Expository teaching is a suitable method for giving outlines of a subject." (S222)

It is understood from Table 7 that a small part of the participants mentioned about teaching by problem solving, computer-aided teaching, teaching by scenario, demonstration, teaching by games, teaching by analysis and case study method.

In the next step, the participants were asked to draw the images of classroom environment using the SMTs of their preference. Participants' drawings of learning environment and their explanations were examined with four field experts and classified in 5 groups by SMTs of their preference. These groups are summarized in Table 8 and percentages and frequencies for SMTs of their preference and drawings of classroom environment are given in the table.

Table-8. Percentages and frequencies for SMTs preferred by participants in mathematics teaching and drawings of classroom environments.

\begin{tabular}{|c|c|c|c|}
\hline & & $f$ & $\%$ \\
\hline \multirow{3}{*}{ 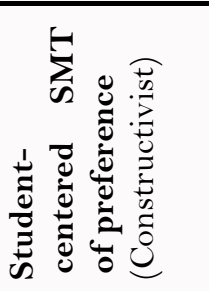 } & $\begin{array}{l}\text { C1: Student-centered SMT of preference - Drawing of a } \\
\text { student-centered learning environment }\end{array}$ & 104 & 36.11 \\
\hline & $\begin{array}{l}\text { C2: Student-centered SMT of preference - Drawing of a } \\
\text { teacher-centered learning environment }\end{array}$ & 27 & 9.38 \\
\hline & $\begin{array}{l}\text { C3: Student-centered SMT of preference - Drawing of a } \\
\text { teacher-centered learning environment with U-shape seating } \\
\text { order which blocks student-student interaction }\end{array}$ & 57 & 19.79 \\
\hline \multirow{2}{*}{ 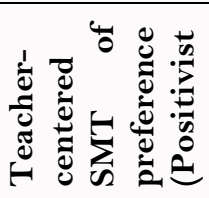 } & $\begin{array}{l}\text { P1: Teacher-centered SMT of preference - Drawing of a } \\
\text { student-centered learning environment }\end{array}$ & 43 & 14.93 \\
\hline & $\begin{array}{l}\text { P2: Teacher-centered SMT of preference - Drawing of a } \\
\text { teacher-centered learning environment }\end{array}$ & 57 & 19.79 \\
\hline
\end{tabular}

Note: C: Student-centered SMT of preference, $\mathbf{P}$ : Teacher-centered SMT of preference.

According to Table 8, majority $(65.27 \%)$ of the participants preferred student-centered teaching, that is, regarded themselves as constructivists. However, considering participants' student-centered teaching drawings, 104 participants designed a student-centered learning environment, 27 design a teacher-centered learning environment, 57 designed a teacher-centered learning environment but with U-shape seating order which blocks student-student interaction. Hence, rate of participants who preferred student-centered teaching in practice was $36 \%$ which means a decrease compared to what they stated in previous questions. Exemplary drawings of participants who preferred student-centered teaching methods are given below. 
S19
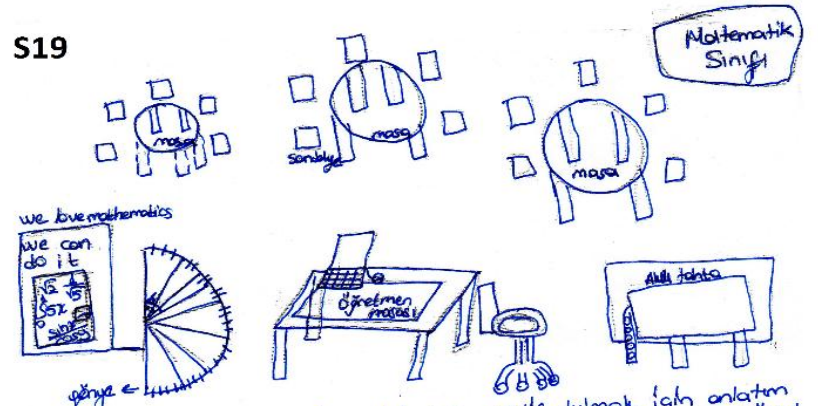

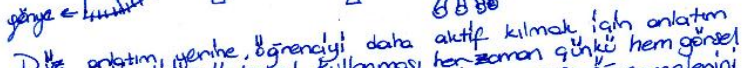

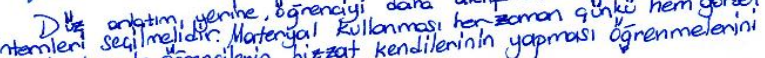
anlanda hemde ogrencilerin

Figure-1. Exemplary drawings of student-centered learning environment and SMTs of preference.

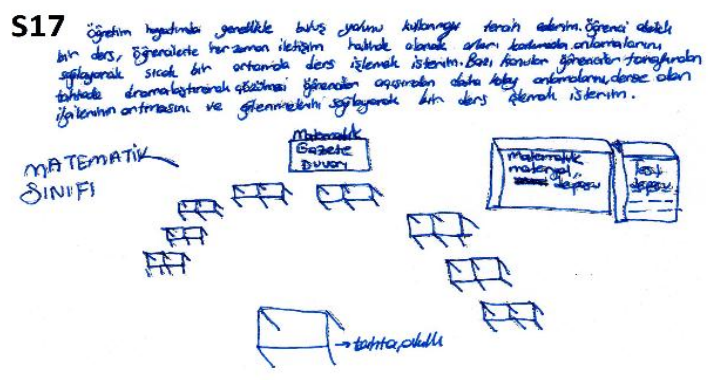

Figure 1 presents explanations and drawings of S19 and S17 who reported that they mainly preferred to use student-centered SMTs. Their explanations are given below:

"S19: Instead of expository teaching, different expression methods should be chosen to make the student more active. Materials should be used at all times, because both visuality and the students' individual effort will make it "easier for them to learn."

"S17: I choose using exploring method in my teaching life. I would like to teach a lecture with a student-oriented course, by enabling them to understand them without fear, by always communicating with the students. Some topics can be demonstrated with drama by the students and they can be understand more easily by the students, I would like to teach the lessons by making them have fun to increase their interest in the lesson."

According to the learning environment designed by and explanations made by S19, it seems that they attached importance to group work, technology (smartboard and computer), and interaction with materials. It is understood from the drawings and explanations by S17 that they similarly highlighted group work, and use of technology (smartboard) and material (mathematics material storage, mathematics newspaper panel). Whereas S19 stated in their explanations that they preferred the use of student-centered SMTs for allowing students to learn on their own, S17 put emphasis on learning by exploring and teaching by scenario. To account for this emphasis, the participant stated that student-centered teaching increases student's attention in courses, they are in communication all the time, and therefore, can learn something from their peers.
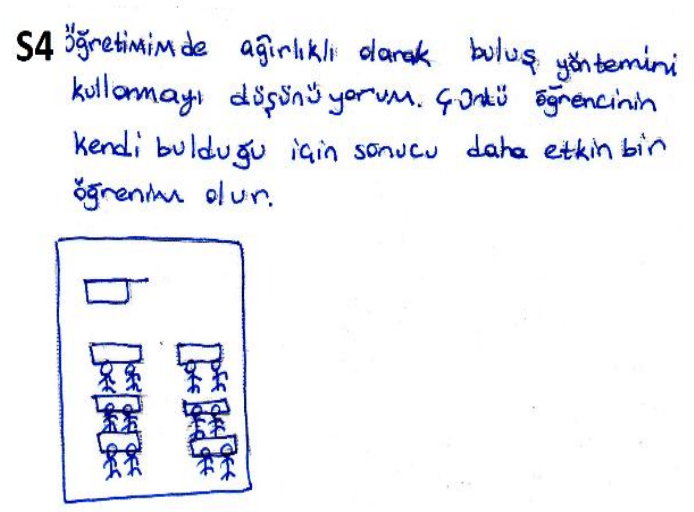

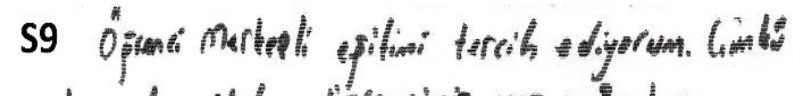

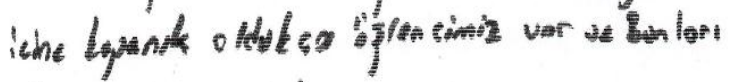 kotonmanar gerrek.}

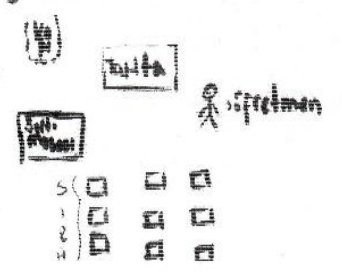

Figure-2. Exemplary drawings of teacher-centered learning environment with student-centered SMTs of preference.

Explanations and drawings by $\mathrm{S} 4$ and $\mathrm{S} 9$ are presented in Figure 2. Their explanations about the drawings are given below:

"S4: I think of using the exploring method in teaching. In this way, the student becomes more active in learning, because he I she will discover it himself."

"S9: I prefer student-centered teaching. Because we have many students who are introvert and we have to win them."

While S4 and S9 stated that they preferred student-centered teaching, they did not include any additional teaching method in their drawings and used a seating order as in a traditional classroom environment.
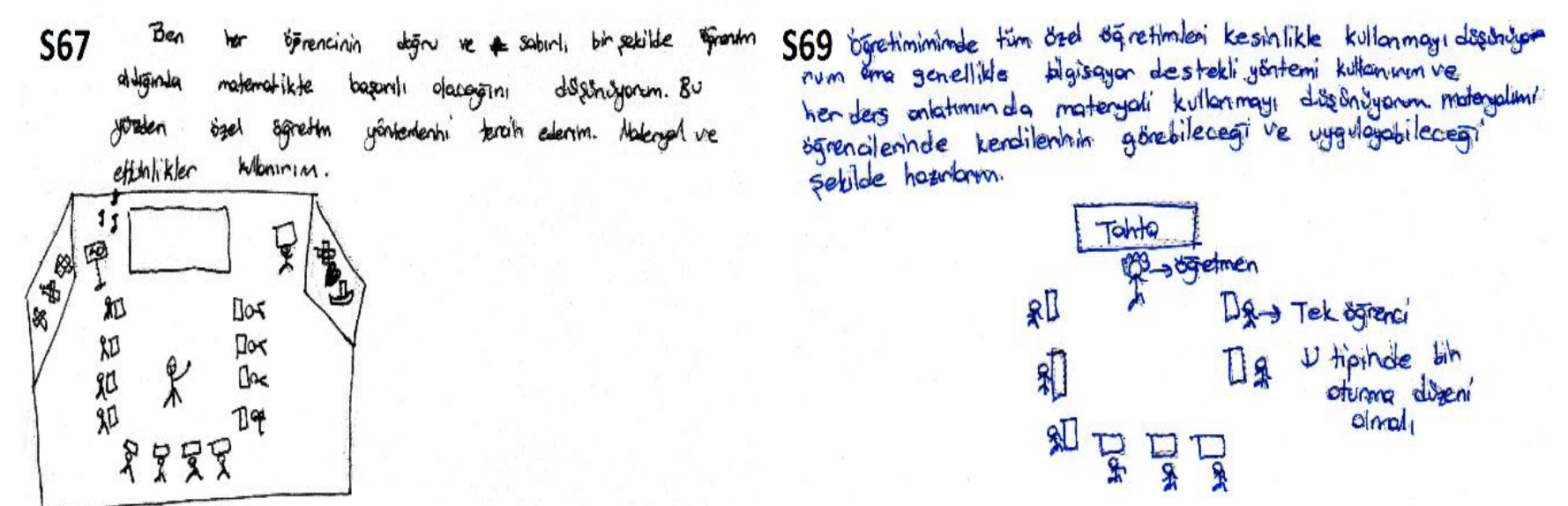

Figure-3. Exemplary drawings of teacher-centered learning environment with student-centered SMTs of preference but with U-shape seating order which blocks student-student interaction.

Source: Scanned images of student drawings and explanations. 
Figure 3 presents teacher-centered learning environments which were designed with student-centered SMTs but in a U-shape seating order and were supported by material and equipped with computer, therefore putting computer in the center, in which student-student interaction was blocked, along with relevant exemplary explanations. Their explanations about the drawings are given below:

"S67: I think every student will be successful in mathematics when taking training accurately and stable. Therefore, I choose using different teaching methods, materials and activities."

"S69: I definitely think of using all the special methods in my teaching, but I usually prefer computer-aided teaching. In addition, I think of using material in every lecture. I prepare my materials in environments where students can see and apply."

Both S67 and S69 stated that they would use special teaching methods they had learned in mathematics teaching when appropriate and emphasized that they would use materials. In the learning environment designed by S67, student was placed in the center, additional teaching materials were used but seating order was in U shape, which means that student-student interaction was blocked as students sit on their desks in a single file. As for S69's drawing, although computer-aided teaching was preferred, how students were sitting in a single file and in U-shape sitting order makes the classroom computer-centered despite being equipped with computer.

It is understood from Table 8 that a part $(34.72 \%)$ of the participants preferred teacher-centered teaching SMTs and therefore regarded themselves as positivists. As for the drawings by participants who preferred teachercentered teaching, 43 participants designed a student-centered environment while 57 participants designed a teacher-centered environment. Exemplary drawings of participants who preferred teacher-centered teaching are given below.

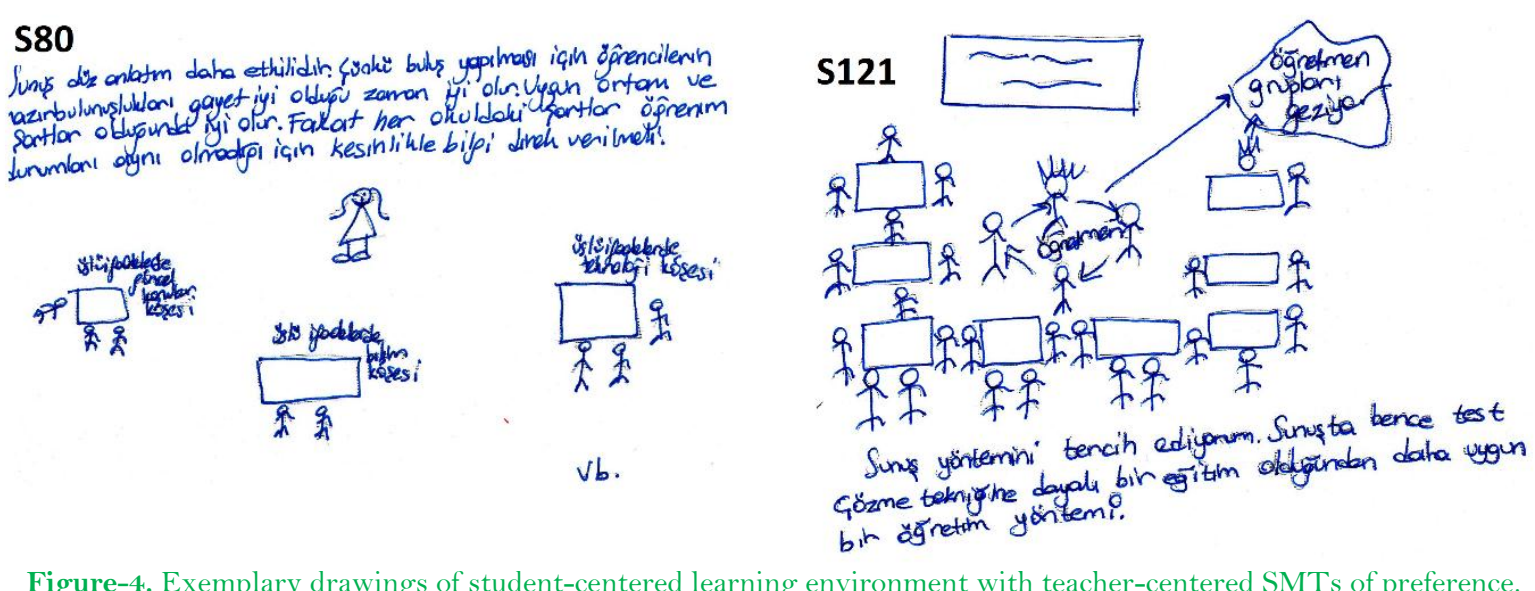

Figure 4 shows the drawings and explanations by S80 and S121 who preferred teacher-centered teaching. Their explanations about the drawings are given below:

“S80: Expository teaching is more effective. Because, in order to make a discovery, students' readiness must be provided. Exploring method is effective to use when appropriate environment and conditions are provided. But since the conditions, especially educational conditions, in each school are not the same, information must be given directly."

"S121: I choose expository teaching method. This method is also suitable for being based on teaching method based on test solving techniques."

S80 stated that information should be given directly as not every student has the same level of readiness, and therefore, they preferred expository teaching. Regarding the learning environment designed by the participant, however, how they attached importance to group work, association of subjects with daily life and the use of technology could be understood from the task sharing among the students (current topic corner for exponentials, science corner for exponentials and technology corner for exponentials). Similarly, S12 1 emphasized group work in their designed learning environment although they stated that they preferred expository teaching since testing has a key role in our educational system.
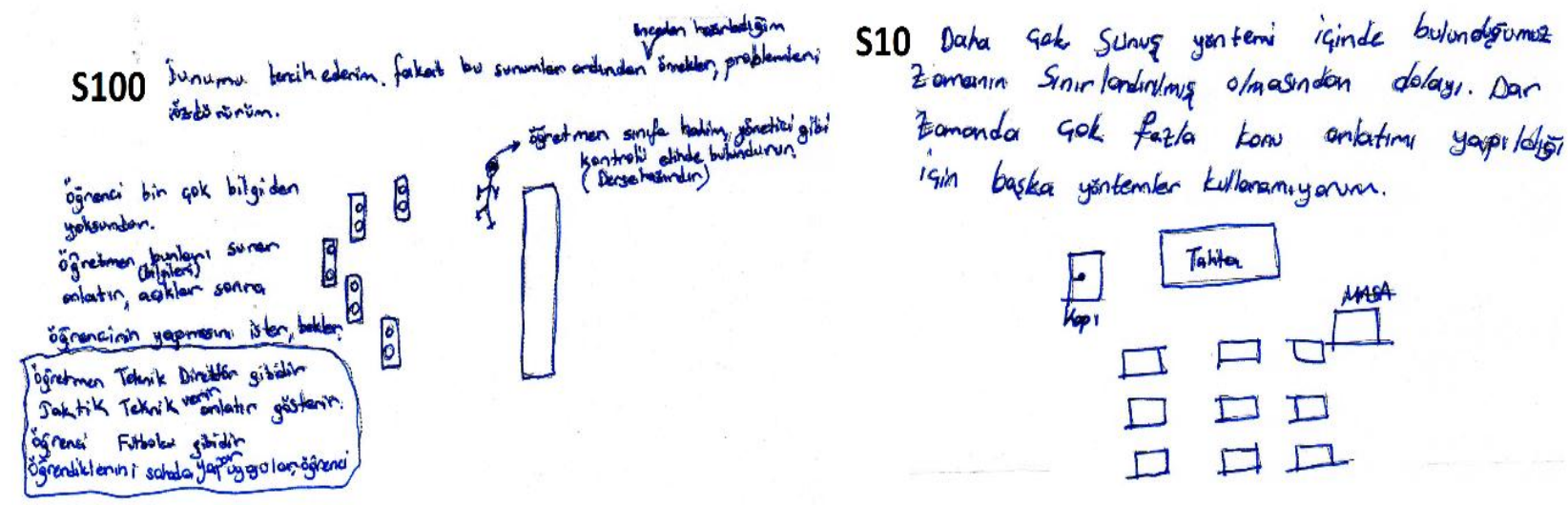

Figure-5. Exemplary drawings of teacher-centered learning environment and SMTs of preference.

Figure 5 presents the exemplary drawings of student-centered learning environment and SMTs of preference $\mathrm{S} 100$ and S10 stated that they preferred expository teaching. Their explanations about the drawings are given below: "S100: I choose expository teaching method. But after the presentations, I solve the problems I prepared before. The student lacks a lot of information. The teacher presents, explains and explains them. Then (s)he asks the student to do it and waits. The 
teacher dominates the class, retains control like a manager (ready for class). The teacher is like a coach, tells and shows tactics and techniques. The student is like a football player and applies what (s)he has learned on the field."

"S10: I use the most expository teaching method. Because the time we are in is limited. I do not use any other methods, as too many topics are narrated in a short time."

The participants explained that teacher has the control like a manager in this way. S1oo likened a teacher to a football coach and students to football players. They showed in their drawing that the football couch tells about and shows tactics while football players apply what they learned on the pitch. The remarkable point in this participant's drawing is that seating order of the classroom was in such a way that all students could see the teacher differently from the traditional order. S10 mentioned that they preferred expository teaching due to limited time and intense subjects. It is seen that their learning environment was in the traditional seating order and did not utilize any additional teaching materials or technologies.

\section{Discussion and Results}

It was aimed with this study to address mathematical and mathematics educational values of mathematics students receiving pedagogical formation in regard to constructivist and positivist approaches and examine the effect of their values on their preferred SMTs. Firstly, it was examined whether there were differences among students' values, and a significance difference was found between their positivist and constructivist values in favor of the latter. Students' constructivist values might have been because the study was conducted at the end of the term. Indeed, majority of the students stated that they had not had teachers who taught by student-centered alternative methods in their previous educational lives and they had seen these concepts for the first time in the formation training. The Secondary Education Mathematics Curriculum (MEB, 2013) states that an approach placing the student in the center is adopted and emphasize the importance that teacher plan well-structured activities (structure educational materials and mathematical learning environments/activities in which materials will be used) to achieve active participation in the course beforehand. Within the scope of the course, students examined the said curriculum, and the applications were performed in line with the specified contents. In this sense, one can say that it was an expected outcome that the students became knowledgeable of the curriculum and the different and new teaching methods in more detail, and therefore, they were sympathetic towards the values dominated by constructivist approaches. This result coincides with the results of other studies in Turkey (Durmus and Bıçak, 2006; Durmus et al., 2008; Dede, 2009). When compared by gender, a significant difference was found in favor of female participants in regard to constructivist values while there was no significant difference between female and male participants who had positivist values. In their study examining science and technology, mathematics, and classroom teachers in terms of constructivist and positivist values, Durmus et al. (2008) found a significant difference in favor of constructivist values. Similarly, Durmus (2011) concluded in the study investigating preservice mathematics teachers' value profiles and opinions on modelling that there was a significant difference between levels of having positivist and constructivist values in favor of the latter. According to another result of the said study, when comparing the participants with positivist values by gender, there was a significant difference in favor of male participants but no significant difference was found between female and male participants with constructivist values. This result is in line with the result of the present study. Dede (2009) examined the values of preservice primary and secondary education mathematics teachers by gender and department and concluded that preservice teachers tended to adopt constructivist values rather than positivist values in mathematics teaching. The same study concluded no statistically significant difference between values by gender.

In this study, majority of the participants stated that the most frequent method in their educational lives had been expository teaching. Most of them reported that they had been taught only with expository teaching in mathematics courses and had not performed any experiments in science courses. In parallel with this result, Temizöz and Ozgün-Koca (2009) investigated the teaching methods used by mathematics teachers and concluded that most of them were sympathetic towards expository teaching and used it in their courses. According to the TIMSS-1999 National Report of Turkey (MEB, 2013) teachers spare 41\% of their time for teaching by expository teaching and 12\% for experiments-demonstrations; in the light of this finding, the result that Turkey is one of the countries which use expository teaching the most and perform experiments the least in science courses (Bağcı-Kılıc, 2002) coincides with this finding.

Several studies in the literature have concluded that learning by exploring is more effective in increasing the achievement than traditional methods (Pesen et al., 2000; Akar, 2006; Balım, 2009; Akın and Pesen, 2010). In the present study, too, learning by exploring was the SMT found to be the most effective by participants in mathematics teaching. The fact that learning by exploring was deemed much more effective than traditional methods in the study (Castronova, 2002) coincides with the results of studies in the literature given that a main objective of teaching is to increase student achievement. Moreover, how participants found learning by exploring more effective and efficient supports the idea that they had constructivist values.

Learning by exploring, group work and teaching by scenario were the most emphasized SMTs among the ones found difficult to use in mathematics teaching by the participants. For the reason why these methods were difficult, they stated that class sizes were great, good planning was required, and applications would take time. This result is in line with the results in the literature (Seferoğlu, 2004; Temizöz and Ozgün-Koca, 2008; Soylu, 2009). In the study aiming to examine on what level fourth-grade students of classroom teaching can use methods and techniques in mathematics teaching, Soylu (2009) concluded that majority of the students found themselves competent or partially competent in direct instruction, definitions, rules and question and answer methods and techniques while they regarded themselves incompetent in exploring, cooperation, demonstration, games, case study and problem posing and solving. Seferoğlu (2004) subjected fourth-year students of Computer Education and Instructional Technologies (CEIT) to a 4-point Liker scale of 35 items about teaching to determine on what level preservice teachers have the competencies expected by the Ministry of National Education. Considering the distribution of answers to the related items, the answers were on a "good" level on average, the "teaching by question-answer method" item had the highest mean and the "teaching by roleplaying" had the lowest mean. In the 
study by Temizöz and Ozgün-Koca (2008) majority of mathematics teachers stated that they thought instructional plans prepared according to teaching by exploring would take so much time and would not be suitable for crowded classrooms although they liked the plans. Similarly, Castronova (2002) stated that preparation and learning stages of teaching by exploring require so much time and classrooms are too small or big to use this method.

Learning by exploring, expository teaching, and group work were the primary SMTs to be most frequently preferred by participants in their own teaching. This result is in line with the finding that learning by exploring was the SMT found by the participants effective in mathematics teaching and supports the opinion that these participants had constructivist values.

Mathematics students attending the Pedagogical Formation Program were asked to draw about SMTs of their preference and a classroom environment utilizing these SMTs, and their drawings were classified in five groups. Majority (65.27\%) of the participants were found to prefer student-centered teaching methods while less than half $(34.72 \%)$ of them preferred teacher-centered methods. This result can be interpreted as the indicator that majority of participants had constructivist values.

Majority of participants who preferred student-centered teaching and made student-centered drawings put emphasis on group work and teaching by scenario and stated that they chose these methods because they allow for students' self-learning and retentive learning, increase interest in the course, improve students' communication skill and support peer learning. It is similarly stated in the literature that a more retentive and functional learning is achieved with these methods as they help students associate information with daily life rather than memorizing it and allow them to explore information, therefore making information more meaningful and that these methods increase individual's confidence and interest in the course and have positive impacts on academic achievement (Altun, 2002; Akar, 2006; Baki, 2008).

Majority of participants who preferred teacher-centered teaching and made teacher-centered drawings showed that teacher had the control in the classroom and they did not utilize any additional teaching materials or technologies in their drawings. Similarly, Doğan (2004) concluded that the methods and techniques most preferred and used by classroom teachers were direct instruction and question-answer. Temizöz and Ozgün-Koca (2008) found that majority of secondary school mathematics teachers used question-answer technique and direct instruction method.

In mathematics teaching, one should attach importance not only to the cognitive aspect but also the affective aspect of mathematics like values (Dede, 2007). Hence, this matter should be addressed in preservice and in-service trainings provided for teachers, and applied studies should also be conducted. In this study, students' value profiles and methods/approaches they thought they would use in teaching process were examined and found to be coherent in general. Nevertheless, it is also deemed important to investigate the relationship between value profiles of teachers and their practices during teaching to test the accuracy of this result.

\section{References}

Adıgüzel, A., 2013. Competence levels of teachers of the field based on pedagogical formation related to the teaching-learning process. Sakarya University Journal of Educational Sciences Institute, 3(2): 48-64.

Akar, F., 2006. The effect of discovery learning on the academic achievement of students in the second grade mathematics lesson. Unpublished Master Thesis, Cukurova University Institute of Social Sciences, Adana.

Akın, M.F. and C. Pesen, 2010. The effects of the full cube model on learning products in obtaining identities. Dicle University Journal of Ziya Gökalp Education Faculty, 14: 86-102.

Alkan, H. and M. Altun, 1998. Mathematics teaching, 41-56. Anadolu University Open Education Faculty Publication, No:591. Eskişehir, Turkey.

Altun, M., 2002. Mathematics teaching methods. Anadolu University. pp: 41-56.

Altun, M., 2004. Mathematics education in the second grade (6th, 7 th and 8 th grades) of primary education. Bursa: Alfa.

Altun, M., 2014. Teaching mathematics in high schools for education faculties and math teachers. Bursa: Aktüel.

Arslan, S. and I. Ozpınar, 2008. Teachers' qualifications: Comparison between primary school curriculum expectations and teachers acquisitions in education faculties. Necatibey Faculty of Education Electronic Journal of Science and Mathematics Education, 2(1): 38-63.

Bağcl-Kılıc, G., 2002. Turkey and the world "in science teaching. V. National Science and Mathematics Education Congress September 2002, METU, Ankara, (63):12-18.

Baki, A., 2008. Mathematics education from theory to practice. Ankara: Letter Education Publishing.

Balım, A.G., 2009. The effects of discovery learning on students' success and inquiry learning skills. Eurasian Journal of Educational Research, 35: 1-20.

Biber, A.C. and A. Tuna, 2015. Views of teacher candidates with pedagogical formation in department of mathematics on teaching practice course. Başkent University Journal of Educatıon, 2(2): 131-140.

Bishop, A., 2008. Values in mathematics and science education: Similarities and differences. The Mathematics Enthusiast, $5(1): 47-58$.

Bishop, A., B. Clarke, D. Corrigan and D. Gunstone, 2006. Values in mathematics and science education: Researchers' and teachers' views on the similarities and differences. For the Learning of Mathematics, 26(1): 7-11.

Bishop, A., G. FitzSimons, W.T. Seah and P.C. Clarkson, 1999. Values in mathematics education: Making values te 7 aching explicit in the mathematics classroom. Paper Presented at the Combined Annual Meeting of the Australian Association for Research in Education and the New Zealand Association for Research in Education, Melbourne, Australia.

Bishop, A.J., 2001. What values do you teach when you teach mathematics? Teaching Children Mathematics, 7(6): 346-346.

Cao, Z., W.T. Seah and A.J. Bishop, 2006. A comparison of mathematical values conveyed in mathematics textbooks in China and Australia. In Mathematics education in different cultural traditions-a comparative study of East Asia and the West. US: Springer. pp: 483493.

Castronova, J.A., 2002. Discovery learning for the 21 st century: What is it and how does it compare to traditional learning in effectiveness in the 21 st century. Action Research Exchange, 1(1): 1-12.

Chin, C., Y.C. Leu and F.L. Lin, 2001. Pedagogical values, mathematics teaching, and teacher education: Case studies of two experienced teachers. In F.-L. Lin \& T. J. Cooney (Eds.), Making sense of mathematics teacher education. Dordrecht, The Netherlands: Kluwer Academic Publishers. pp: 247-269.

Dede, Y., 2006a. Mathematical values conveyed by high school mathematics textbooks. Educational Sciences: Theory \& Practice, 6(1): 118132.

Dede, Y., 2006a;2006b. Values in Turkish middle school mathematics textbooks. Quality and Quantity, 40(3): 331-359.

Dede, Y., 2007. The place of values in mathematics teaching. Abant Izzet Baysal University Faculty of Education Journal, 7(1): 12-25.

Dede, Y., 2009. Turkish preservice mathematics teachers "e mathematical values: Positivist and constructivist values. Scientific Research and Essays, 4(11): 1229-1235.

Doğan, C., 2004. Classroom teachers' views about the lessons and their preferred teaching methods: Istanbul example. Turkish Journal of Educational Sciences, 2(2): 193-203. 
Dündar, H. and E.T. Karaca, 2013. Metaphors of formation students regarding pedagogical formation program. The Journal of the Industrial Arts Education Faculty of Gazi University, 30: 19-34.

Durmus, S., 2011. A review of the values and modeling levels of elementary mathematics teacher candidates. Educational Sciences: Theory \& Practice (KUYEB), 11(2): 1055-1071.

Durmus, S. and B. Biçak, 2006. A scale for mathematics and mathematical values of pre-ervice teachers. Paper Presented at the 3rd International Conference on the Teaching of Mathematics, Istanbul, Turkey.

Durmus, S., B. Bıcak and S. Cakır, 2008. Examining the mathematics and mathematics education values of science and technology, mathematics and classroom teachers in terms of different variables. Values Education, 6(16): 93-112.

Eraslan, L. and D. Cakıci, 2011. Pedagogical formation program students' attitudes towards teaching profession. Kastamonu Education Journal, 19(2): 427-438.

FitzSimons, G., W. Seah, A. Bishop and P. Clarkson, 2001. Beyond numeracy: Values in the mathematics classroom. 24th Annual MERGA Conference.

Gömleksiz, M.N. and A.U. Kan, 2007. The basic principles and approaches on which new primary education programs are based. Eastern Anatolia Region Research, 5(2): 60-66.

Kartal, T. and O. Afacan, 2012. Examining the attitudes of prospective teachers who have received pedagogical training education on teaching profession. Mehmet Akif Ersoy University Journal of Education Faculty, 12(24): 76 - 96.

Kartal, T., N. Oztürk and G. Ekici, 2012. Developing pedagogical content knowledge in preservice science teachers through microteaching lesson study. Procedia-Social and Behavioral Sciences, 46: 2753-2758.Available at: https://doi.org/10.1016/j.sbspro.2012.05.560.

Kus, D., 2009. Investigation of the effectiveness of primary education programs, implicit program, and out-of-school factors according to the opinions of 8th grade primary school students and teachers. Unpublished Doctoral Dissertation, Yıldız Technical University, Institute of Social Sciences, Istanbul.

Lim, C.S. and P. Ernest, 1997. Values in mathematics education: What is planned and what is espoused? In Brirtish Society for Research into Learning Mathematics. Proceedings of the Day Conference held at University of Nottingham. pp: 37-44.

Liman, M.A., M.B. Ibrahim and Y. Ismail, 2013. Exploration and evaluation of the mathematical values inculcation instrument. Journal of Language and Culture, 4(1): 10-17.

Luttrell, V.R., B.W. Callen, C.S. Allen, M.D. Wood, D.G. Deeds and D.C. Richard, 2010. The mathematics value inventory for general education students: Development and initial validation. Educational and Psychological Measurement, 70(1): 142-160.Available at: https://doi.org/10.1177/0013164409344526.

MEB, 2013. Secondary mathematics lesson (9th, 10th, 11 th and 12th grades) curriculum [mathematics curriculum for the secondary schools: $9,10,11$ and 12th grades]. Ankara: National Education Publications.

Mustang, T., 2002. New approaches to teacher training in the world and Turkey. Educational Administration: Theory and Practice, 8(1): $115-127$.

Nartgün, S.S. and I. Gökçer, 2014. Metaphoric perceptions of prospective teachers who receive pedagogical training education regarding their professions, their future, employment and educational policies. E-International Journal of Educational Research, 5(4): 57-69.

Ozkan, H.H., 2012. Examining the attitudes of prospective teachers in the teaching formation program regarding the teaching profession (SDU Example). Journal of Ahi Evran University Kırşehir Faculty of Education, 13(2): 29-48.

Pa, N.A.N. and R. Tapsir, 2013. Analysis of instruments measuring values of mathematics education. Procedia-Social and Behavioral Sciences, 90: 449-457.Available at: https://doi.org/10.1016/j.sbspro.2013.07.114.

Pathania, A., 2011. Teachers' role in quality enhancement and value education. Academe, 14(1): 19-26.

Pesen, C., A. Odabas and R. Bindak, 2000. On the mathematics teaching methods used in primary schools. Education and Science, 25(118): $32-34$.

Polat, S., 2013. Investigation of the attitudes of students from pedagogical formation certificate programs and faculties of education on the prof. E-International Journal of Educational Research, 4(2): 48-60.

Seah, W.T., A.J. Bishop, G.E. FitzSimons and P.C. Clarkson, 2001. Exploring issues of control over values teaching in the mathematics classroom. In Annual Conference of the Australian Association for Research in Education, Fremantle, Australia.

Seferoğlu, S.S., 2004. Teacher candidates' evaluation of themselves in terms of teacher competencies. Hacettepe University Faculty of Education Journal, 26: 131-140.

Soylu, Y., 2009. A study on the pre-service teachers' proficiency in using teaching methods and techniques in mathematics lessons. Mersin University Faculty of Education Journal, 5(1): 1-16.

Süral, S. and E. Saritas, 2015. The investigation of the students of pedagogical formation towards teaching profession qualifications. Mersin University Journal of the Faculty of Education, 11(1): 62-75.

Swanader, M. and R. Soedjadi, 1988. Values, mathematics education, and the task of developing pupils' personalities: An Indonesian perspective. Educational Studies in Mathematics, 19(2): 193-208.Available at: https://doi.org/10.1007/978-94-017-2209-4_5.

Temizöz, Y. and S.A. Ozgün-Koca, 2008. The instructional methods that mathematics teachers use and their perceptions on the discovery approach. Education and Science, 33(149): 89-103.

Temizöz, Y. and S.A. Ozgün-Koca, 2009. Opinions of mathematics teachers on the application of teaching through presentation in mathematics teaching. Elementary Education Online, 8(1): 88-102.

Tepeli, Y. and M. Caner, 2014. Pedagogical formation program students' opinions about teaching practice [teacher certificate program students 'opinions on teaching practice]. Journal of Educational Sciences Research, 4(2): 313-328.

Yenice, N. and B. Ozden, 2017. Opinions of the prospective biology teachers who participated in the pedagogical formation certificate program regarding the teaching profession. Duzce University Journal of Social Sciences Institute, 7(2): 89-105. 